\title{
The Correlation of Salaries and Teacher Performance in Madrasah Ibtidaiyah level
}

Sriyadi

Madrasah Ibtidaiyah (MI) Nurul Huda Gowak Temanggung

azkayayak@gmail.com

\begin{abstract}
This study aims to determine whether there is a significant relationship between the honorary teacher salaries with teacher performance at MI Nurul Huda Gowak in 2019. In this study, the population was eight honorary teachers at Madrasah Ibtidaiyah (MI) Nurul Huda Gowak, Pringsurat, Temanggung in 2019. Because there are eight teachers, all of which will be sampled, this study is a population study. The data was gained through questionnaires. Data were analyzed quantitatively by Spearman correlation with SPSS 12.0 statistical software. The result shows that there is no significant relationship between the honorary teacher salaries with teacher performance that can be known from the results of the calculation using SPSS 12.0. The calculation using Spearman's rho obtained 0.518, while $\mathrm{r}$ value in Sig (2-tailed) with $d f 8$ is 0.188 . It turns out that $r_{o}$ (magnitude: 0.518) is greater than Sig (2-tailed) 0.188. Because $r_{o}$ is bigger than Sig (2-tailed), then the null hypothesis (Ho) is accepted. It meant that there is no positive correlation between variables teacher salaries and teacher performance. Based on this fact, it can be explained that teacher salaries have nothing to do with teacher performance.
\end{abstract}

Keywords: Honorary teacher salaries, teacher performances, correlation INTRODUCTION

Teachers are an important element in the education system, especially in schools and madrasas (Mart, 2013: 6). All other components, starting from the curriculum, facilities, costs, etc. will not mean much if the essence of learning so that interactions with teacher students are not 


\section{Mudarrisa: Jurnal Kajian Pendidikan Islam, Vol. 11, No. 2, 2019}

qualified. All other components, especially the curriculum will "live" if implemented by the teacher.

The school principals and supervisors do not easily obtain data and observe teacher performance in front of students. The teacher tries to show the best performance both in the planning and implementation aspects of students only at the time of the visit by principals or supervisors. Furthermore, he will return to work as usual, sometimes without preparation and without spirit and enthusiasm high.

The current condition of education requires teachers to be one of the determining factors in improving the quality of education. The success of the administration of education is very much determined by the extent to which the readiness of the teacher in preparing students through teaching and learning activities (Dangara, 2016: 11).

In the context of the development of the education sector, the teacher is a very central role holder. The teacher is the heart of education. Without the pulse and active role of the teacher, any policy of renewal of education as sophisticated as it would still be in vain. No matter how good and how modern an educational curriculum and strategic planning are designed if, without qualified teachers, it is useless (Alsubaie, 2016: 2). That is, good and superior education will still depend on the quality conditions of teachers.

This was stressed by UNESCO in the report of the International Commission on Education for Twenty-first Century, namely "improving the quality of education first depends on improving recruitment, training, 


\section{Mudarrisa: Jurnal Kajian Pendidikan Islam, Vol. 11, No. 2, 2019}

social status, and working conditions of teachers; they need knowledge and skills, personal character, prospects professional, and appropriate motivation if you want to meet the expectations of educational stakeholders " (Delors et al., n.d.). Therefore, efforts to improve the professionalism and welfare of teachers are a necessity (Tanang \& Abu, 2014). Teachers are required to have quality when presenting teaching materials to students. They are not only required to be able to transform a set of knowledge (cognitive domain) and aspects of skills (psychomotor domain) but also has the responsibility to manifest things related to attitudes (affective domain) (Kasilingam et al., 2014: 30). Teachers are a group of people who have faculties of reasoning, devotion, and knowledge. They have the characteristics: moral, listening to the truth, able to stay away from the falsity of illusions, worship God, be wise, realize and take experiences.

Teachers must obtain systematic training programs in order to continue to have high professionalism and be ready to innovate. Teachers must also get the respect and welfare they deserve for their service. Thus, every innovation and update in the field of education can be well received and lived. With increasing teacher quality, teachers will be able to produce superior values in the practice of education. Thus, human figures were born who had the characters: Faithful, Trustful, Professional, Enthusiastic and Highly Motivated, Responsible, Creative, Discipline, Caring, Life-Long Learners, Visionaries, Being Exemplary, Motivating, Inspiring, Empowering, Civilizing, Productive, Responsive and 


\section{Mudarrisa: Jurnal Kajian Pendidikan Islam, Vol. 11, No. 2, 2019}

Aspirational, Anticipatory and Innovative, Democratic, Fair, and Inclusive.

Expecting the presence of a teacher who has the competence, idealism, and professionalism to improve the quality of education, of course, depends on the level of welfare obtained by the teacher in return for the dedication of his professional duties. Therefore, the Law No. 14 of 2005 concerning Teachers and Lecturers, which was originally expected to be an important foundation and milestone in increasing idealism and improving the quality, welfare, and dignity of teachers, should be properly implemented. Thus, the profession as a teacher becomes truly noble and dignified. The teacher is no longer considered an unsung hero. But, the services of teachers are really heeded and valued properly and humanely.

In the National Education System Law article 40 paragraph 1 (a) states, teachers have the right to earn adequate and adequate social security income and guarantees (National Education System Law, 2005: 36). A clear difference between public and private schools is the status of the manager, the teaching staff, and the source of funding. Public schools are managed by the government, while private schools are managed by foundations or private institutions. Most public school teachers are civil servants (PNS), while most private school teachers are employees of foundations or private institutions, although there are public teachers who are seconded in private schools. Regarding funding sources for school operations, the majority of public school funds come from the government and student guardian contributions. While the funding sources of private 


\section{Mudarrisa: Jurnal Kajian Pendidikan Islam, Vol. 11, No. 2, 2019}

schools mostly come from the contributions of guardians of students and school businesses and of course a small portion of government funds, for example through school operational assistance.

Another difference is regarding the quality of schools, the learning process, curriculum, teacher salaries, and others. Each school, both public and private, of course, varies in quality and learning process. For the curriculum, most public schools follow the national curriculum, while many private schools integrate the national curriculum and specific curricula according to the characteristics of each school. In terms of salary, most of the public school teachers are civil servants, of course, greater than private school teachers who are paid by a foundation or management agency. Although it is true that for some favorite private schools the salary of a teacher can equal a private teacher, but of course the workload is heavier.

The commitment to improve teacher welfare can be used as a momentum to revive teacher idealism in developing Indonesian civilization. So, the future of Indonesia can be more advanced, quality, cultured, intelligent, and can compete in the world arena. However, the problem is how the agenda can be implemented and realized in concrete, concrete, and based on political will and the seriousness of the government's determination. Apart from the many national problems that ensnare us, in the context of the development of the education sector, a serious commitment to continuing to improve the quality and welfare of teachers is something that cannot be bargained anymore, if we really want 
to seriously develop this nation to become more civilized. Therefore, qualified and prosperous teachers play a very central role in the education process.

The author still expects the government's strategic role in improving the welfare, dignity, and dignity of teachers. The government must commit to implementing Law no. 14 of 2005 concerning Teachers and Lecturers, so that the development of national civilization through the education sector can run in accordance with the hopes and ideals of this nation's independence. A nation with dignity is a nation that wants to glorify and improve the welfare of teachers by rolling out certification for teachers with an S1.

Likewise, what happened at MI Nurul Huda Gowak, Pringsurat Temanggung Regency, that the average income of teachers was devoted to Rp. 250,000.00 which is very far from the feasible and regional minimum wage (UMR) district of Temanggung. Even though the performance of teachers must be in accordance with the National Education System Law and the Laws of Teachers and Lecturers, who demand S1 qualifications and educate students (Observation Results at MI Nurul Huda Gowak on 12 February 2019).

Study and examine the discourse above, the researchers wanted to take the research under the title The correlation between the administration of the welfare of teachers with teacher performance in MI Nurul Huda Gowak District of Pringsurat County Waterford. 


\section{Mudarrisa: Jurnal Kajian Pendidikan Islam, Vol. 11, No. 2, 2019}

\section{METHODS}

This research was conducted in MI MI Nurul Huda, Gowak, Pringsurat, Temanggung. This research is correlation research Instruments research is a tool used to measure the phenomenon and social observed (Sugiyono, 2007: 103), that the variables consisted of teacher salaries and teacher performances. Population used in this research is eight honorary teachers at MI Nurul Huda, the academic year 2018/2019. Data were analyzed by Spearman correlation using SPSS 12.0. In collecting data in this study, researchers used research instruments is the Questionnaire. This method is the questions arranged chronologically from the general leads to specific ones given to respondents/informants who are usually a list of questions (Arikunto, 1989: 145). The questionnaire was used to find out the variables of honorary teacher salaries by madrassas and teacher performance.

\section{DISCUSSION}

The data result from the questionnaire was analyzed by SPSS 12.0 to find out whether there was a correlation between the salary of honorary teachers and teacher performance. Some steps of the analysis are conducted as follows:

1. Normality test

Testing the normality of the estimated error $\mathrm{Y}$ over $\mathrm{X}$ is done with the aim of whether the population is normally distributed or not. Data normality test in this study uses the Kolmogorov Smirnov method, with the significance level used as a rule for accepting or rejecting normality testing 
or not a data distribution is $\alpha=0.05$. The results of the normality test are shown in Table 1.

Table 1. Tests of normality

\begin{tabular}{lcccccc}
\hline & \multicolumn{3}{c}{ Kolmogorov-Smirnov $(\alpha)$} & \multicolumn{3}{c}{ Shapiro-Wilk } \\
\cline { 2 - 7 } & Statistics & $\mathrm{df}$ & Sig. & Statistics & $\mathrm{df}$ & Sig. \\
\hline Teacher's & .307 & 8 & .025 & .737 & 8 & .006 \\
$\begin{array}{l}\text { Performance } \\
\begin{array}{l}\text { Teacher } \\
\text { Salaries }\end{array}\end{array}$ & .233 & 8 & $.200\left(^{*}\right)$ & .898 & 8 & .275 \\
\hline
\end{tabular}

* This was a lower bound of true significance.

Based on the calculation of the error normality of the honorary teacher performance variable over teacher salaries variable (error normality $\mathrm{X}$ over $\mathrm{Y}$ ), the value of $\mathrm{D}_{\text {calculation }}$ (teacher performance $=0.025$ ) and $\mathrm{D}_{\text {calculation }}$ (teacher salaries $=0.200$ ). It compares with $\mathrm{D}_{\text {table }}$ at significance $(\alpha) 0.05$ with 8 samples $(n=8)$. The $D_{\text {table }}$ value was 0.05 , thus $D_{\text {calculation }}$ of teacher performances $<\mathrm{D}_{\text {table }}$ and $\mathrm{D}_{\text {calculation }}$ of teacher salaries $>\mathrm{D}_{\text {table. }}$ Based on the results of the calculation, the sample of teacher performance that are not normally distributed. While the data teacher salaries was normally distributed. The result of the normality test shown in Table 2.

Table 2. Summary of test for variable normality error of $\mathrm{Y}$ research on $\mathrm{X}$

\begin{tabular}{lllc}
\hline \multicolumn{1}{c}{ Variable } & $\mathrm{D}_{\text {count }}$ & $\mathrm{D}_{\text {table }}$ & inf \\
\hline $\mathrm{X}$ (teacher performance) & 0.025 & 0.05 & not normally \\
$\mathrm{Y}$ (teacher salaries) & 0.200 & 0.05 & normally \\
\hline
\end{tabular}

2. Descriptive Statistics

The descriptive analysis of the correlation between honorary teacher salaries with teacher performance shown in Table 3. 
Mudarrisa: Jurnal Kajian Pendidikan Islam, Vol. 11, No. 2, 2019

Table 3. Descriptive statistics

\begin{tabular}{lccc}
\hline \multicolumn{1}{c}{ Variable } & The mean & Std. Deviation & $\mathrm{N}$ \\
\hline Teacher performance & 69.87 & 5.11 & 8 \\
Teacher salaries & 44.12 & 2.85 & 8 \\
\hline
\end{tabular}

Table 3 shows that teacher performance has a mean (average) of 69.88 while the honorary teacher's salaries are 44.13. The standard deviation is 5.11 for teacher performance and 2.85 for honorary teacher salaries. From the data above, the descriptive statistics between the two variables are in the normal category with a small standard deviation.

\section{Hypothesis Testing}

The hypothesis test in research aimed to investigate the hypothesis, namely: Nil Hypothesis $\left(\mathrm{H}_{\mathrm{o}}\right)$, which states that there is no significant relationship between honorary teacher salaries with the performance of teachers in MI Nurul Huda Gowak in 2019. Data analysis with productmoment correlation with SPSS 12.0 statistical software. This technique is used to test the contribution of variable $(\mathrm{X})$ to $(\mathrm{Y})$. Data from the two variables above are entered into SPSS 12.0 and the following results are obtained as shown in Table 4. 
Mudarrisa: Jurnal Kajian Pendidikan Islam, Vol. 11, No. 2, 2019

Table 2. Correlations test

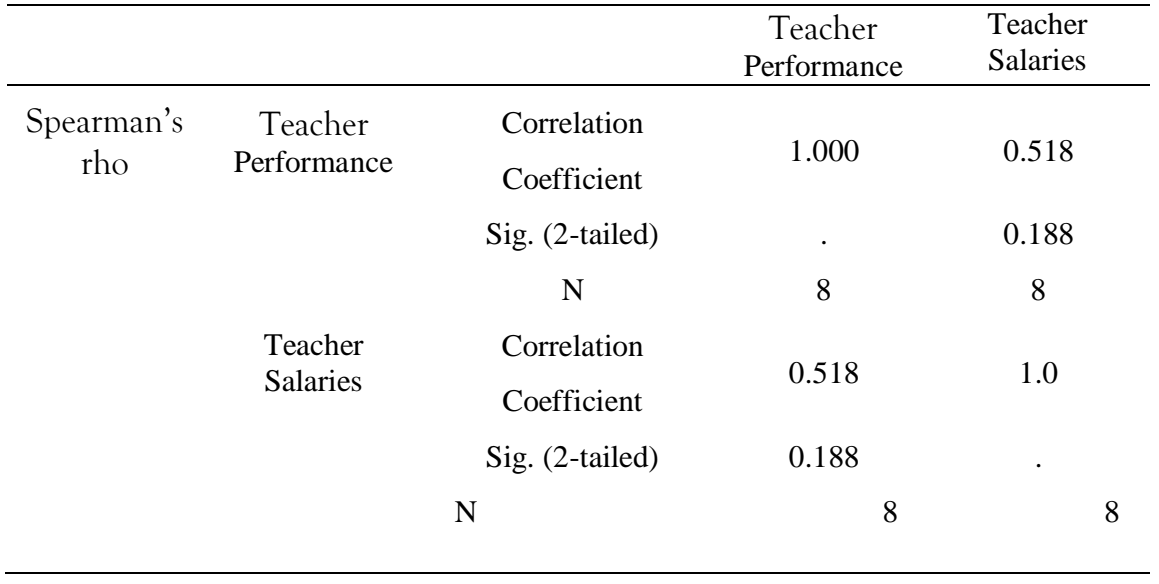

The hypothesis test conducted based on formulated:

$\mathrm{H}_{\mathrm{a}}$ : there is a significant positive correlation between variables $\mathrm{X}$ and $\mathrm{Y}$

$\mathrm{H}_{\mathrm{o}}$ : there is no significant positive correlation between variables $\mathrm{X}$ and $\mathrm{Y}$

The hypothesis test conducted by comparing $\mathrm{r}$ calculation value with $\mathrm{r}$ productmoment table. Table 4.8 shows that the correlation coefficient using Spearman's rho $\left(\mathrm{r}_{\mathrm{o}}\right)$ obtained 0.518 . It compares with $\mathrm{r}_{\text {table }}$ with $\mathrm{df} 8$ in

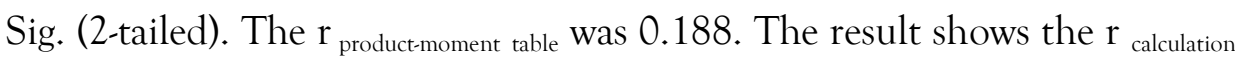
was bigger than $r$ product-moment table. Thus the null hypothesis (Ho) was accepted. It meant, there were no positive correlations teacher performance and the honorary teacher salaries.

In the other research that done in the State Elementary School of Jatiwangi X Bekasi, obtained a result that salary and compensation received by the teachers have influenced the teachers' performances (Widayati, 2019: 8). The same result was also obtained from research that done in the State Junior High School 3 of Batusangkar (Putri, 2017: 5) 
and in the State Senior High School of Ambon (Lesnussa, 2019: 4). The unique thing in this research, there was no correlation between teachers' salary and teachers' performance. Based on the questionnaire and supported by interview research, the 8 respondents have the noble objection of being a teacher. They believe that the salary is not the only one mercy and fortune for them, but they can get it in the other place and the other way. They make the teaching activity is a devotion. And it is in line with the Ministry of Religious Affair "Ikhlas Beramal". The high confidence and the sense of religion of eight respondents strengthen the statement that the low salary has no influence on the teachers' performance. The performance of eight teachers in the Islamic Elementary School Gowak Pringsurat Temanggung, as the respondent is still good even though they receive the low salary. The other factor that supports these things is that they get other income to exclude their salary. They make money from selling the thing and other entrepreneurs. Although there is no correlation, the government keeps the attention wellbeing of honorary teachers.

\section{CONCLUSION}

The correlation between honorary teacher performance and the teacher salaries in MI Nurul Huda, Temanggung were investigated in this paper. The data analysis with product-moment correlation with SPSS 12.0 statistical software. The result shows that $\mathrm{r}_{\text {calculation }}$ was obtained at 0.518 , while their product-moment table was amount 0.188 . Thus the $r_{\text {calculation }}$ was bigger

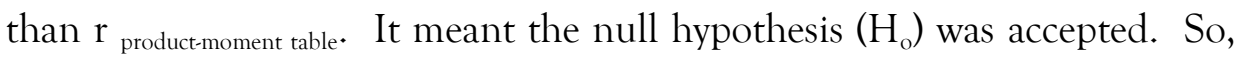


it could be concluded that there are no positive correlations between honorary teacher performance and teacher salaries.

\section{REFERENCES}

Aline, R. al. all (2016) From Malaise to Welfare in Teaching: Elements for Teachers Education, Creative Education, 8, 1193-1212.

Alsubaie, M. A. (2016). Curriculum Development: Teacher Involvement in Curriculum Development. Journal of Education and Practice, 2.

Dangara, Y. (2016). Educational Resources: An Integral Component for Effective School Administration in Nigeria. 11.

Delors, J., Mufti, I. A., Amagi, I., Carneiro, R., Chung, F., Geremek, B., ... Padr, M. (n.d.). Members of the Commission. 46.

Kasilingam, G., Ramalingam, M., \& Chinnavan, E. (2014). Assessment of learning domains to improve student's learning in higher education. Journal of Young Pharmacists, 6(1), 27-33. doi: 10.5530/jyp.2014.1.5

Lesnussa, J. U. (2019). Work Performance Of Teacher On Ambon State High School Indonesia. 8(08), 4.

Mart, Ç. T. (2013). A Passionate Teacher: Teacher Commitment and Dedication to Student Learning. International Journal of Academic Research in Progressive Education and Development, 2(1), 6. 
Mudarrisa: Jurnal Kajian Pendidikan Islam, Vol. 11, No. 2, 2019

Putri, A. (2017). Pengaruh Kompensasi Terhadap Kinerja Guru di SMP Negeri 3 Batusangkar. JMKSP (Jurnal Manajemen, Kepemimpinan, dan Supervisi Pendidikan), 2(1).

Tanang, H., \& Abu, B. (2014). Teacher Professionalism and Professional Development Practices in South Sulawesi, Indonesia. Journal of Curriculum and Teaching, 3(2), p25. doi: 10.5430/jct.v3n2p25

Widayati, K. D. (2019). Pengaruh Kompensasi Terhadap Kinerja Guru Pada Sekolah Dasar Negeri Jatiwaringin X Bekasi. 3(1), 8. 